\title{
PERKEMBANGAN TEKNOLOGI INFORMASI DAN KOMUNIKASI, INOVASI, KEPEMIMPINAN DAN KINERJA PERUSAHAAN: STUDI TRANSFORMASI PT. POS INDONESIA
}

\section{Lambang Andri Prabawa}

andree-yk@yahoo.com

Fakultas Ekonomi Universitas Negeri Jakarta

Mohammad Rizan

dr rizan@yahoo.com

Fakultas Ekonomi Universitas Negeri Jakarta

\begin{abstract}
ABSTRAK
Penelitian ini bertujuan untuk mengetahui seberapa besar pengaruh perkembangan teknologi, kepemimpinan dan inovasi terhadap kinerja PT. POS Indonesia. Metode dalam penelitian ini, menggunakan desain penelitian yang bersifat eksplanatory survey dengan menggunakan pendekatan kuantitatif, yang secara sederhana merujuk pada pengumpulan dan analisis informasi secara statistikal, dengan menggunakan uji statitistik regresi berganda. Skala yang digunakan adalah skala likert yang berguna untuk mengetahui derajat ketidak setujuan ataupun kesetujuan karyawan terhadap pernyataan yang ada pada kuesioner. Dari hasil penelitian melalui pendekatan SPSS dapat dijelaskan bahwa baik perkembangan teknologi, inovasi maupun kepemimpinan, ketiganya memiliki hubungan dan berpengaruh langsung yang signifikan terhadap kinerja. Dengan ini diharapkan hasil penelitian ini dapat memberi masukan bagi PT. POS Indonesia untuk lebih meningkatkan kinerja perusahaan.
\end{abstract}

Kata Kunci: perkembangan teknologi, kepemimpinan inovasi, kinerja

\section{LATAR BELAKANG}

Berbagai teori dan penelitian di bidang organisasi telah mampu menjelaskan dengan baik pentingnya peran dan dampak Sumber Daya Manusia khususnya atas faktor-faktor yang melibatkan organisasi maupun individu yang berpengaruh terhadap kinerja organisasi yaitu antara lain faktor perkembangan teknologi, kepemimpinan maupun inovasi.

Berdasarkan hasil empiris dari penelitian sebelumnya menunjukkan bahwa kepemimpinan berpengaruh positif terhadap kinerja 
organisasi, misalnya penelitian yang dilakukan oleh Baum, Locke, dan Kirkpatrick, Waldman, Ramirez, House, dan Puranam, Zhu, Chew, dan Spangler dalam Özşahin, Zehir dan Acar (2013). Begitu juga dengan hubungan antara inovasi dan kinerja organisasi dari penelitian yang pernah dilakukan oleh Calantone et al.; Cho dan Pucik; Artz et al. Therrien et al.; Gunday et al. dalam Atalay, Afarta dan Sarvan (2013). Sedangkan Mano, Thoyib, Maskie dan Djumahir (2014) menyatakan bahwa kinerja organisasi berkaitan erat dengan kinerja pimpinan, sehingga dalam penelitiannya menyatakan bahwa gaya kepemimpinan, teknologi informasi dan inovasi berpengaruh signifikan terhadap kinerja. Oleh karena itu, orisinalitas penelitian ini adalah untuk mengisi kesenjangan penelitian dengan menawarkan faktor-faktor pada Sumber Daya Manusia dan organisasi untuk meningkatkan kinerja organisasi yang dititikberatkan karena adanya perkembangan dunia teknologi dan informasi.
Karena seperti diketahui, perkembangan dunia teknologi dan informasi menuntut semuanya serba cepat dan tepat. Toleransi terhadap keterlambatan menjadi kecil atau bahkan tidak ada. PT Pos Indonesia yang memiliki fungsi sebagai pengumpul dan pengirim surat ke seluruh penduduk Indonesia dengan menggunakan sumber daya yang ada berupa kantor pos di seluruh Indonesia dan resource tukang pos mulai tergeser posisinya dengan kecanggihan teknologi berupa sms dan email. Masalah waktu kembali menjadi hal utama yang menggeser posisi PT Pos Indonesia dengan sms dan email. Waktu pengiriman PT Pos Indonesia yang membutuhkan waktu dua sampai tiga hari bahkan ada yang satu minggu dinilai sangat lama. Selain itu juga objek bisnis dari perusahaan ini yang hanya berupa personal needed mempersempit gerak PT Pos Indonesia.

Dengan kata lain, pesatnya perkembangan teknologi komunikasi dan informasi dimaksud menyebabkan terjadinya value 
migration besar-besaran dari penggunaan surat sebagai sarana telekomunikasi fisik ke telekomunikasi digital. Dalam hal ini, Pos Indonesia tidak mampu melakukan perubahan internal secara cepat untuk mengimbangi dan menyesuaikan diri dengan kecepatan perubahan eksternal, baik regulasi, situasi kompetisi maupun preferensi konsumen karena banyaknya kendala yang dihadapi baik struktural maupun non struktural. Hal ini tentu saja menuntut PT Pos Indonesia untuk lebih memiliki kemampuan dan inovasi yang tepat dalam menghadapi perkembangan tersebut. Dengan kata lain, diperlukan suatu transformasi dari perusahaan terhadap sumber daya manusia terkait dengan peningkatan dan pengembangan teknologi dengan mempertimbangkan sumber daya manusianya sendiri maupun faktor dari luar.

Selain faktor perkembangan teknologi informasi, beberapa factor lainnya yang dapat dipertimbangkan adalah kepemimpinan dan inovasi itu sendiri. Karena seperti diketahui, Amabile et al. (1996) mengatakan bahwa inovasi sebagai penerapan yang berhasil dari gagasan kreatif dalam perusahaan. Inovasi merupakan sebuah mekanisme perusahaan untuk dapat beradaptasi dalam lingkungan yang dinamis. Oleh karena itu perusahaan dituntut untuk mampu menciptakan penilaian serta ide-ide baru dan menawarkan produk yang inovatif. Dawyer (1987) menyatakan munculnya produk inovasi pada dasarnya adalah untuk memenuhi permintaan pasar sehingga produk inovasi merupakan salah satu yang dapat digunakan sebagai keunggulan kompetitif bagi perusahaan. Inovasi dalam hal ini diartikan sebagai pemanfaatan pengetahuan untuk mentransformasikan proses produk dan jasa secara komersil, guna memperoleh keuntungan. Terminologi inovasi yang berasal dari kata novus sesungguhnya berarti memperkenalkan sesuatu yang baru, sehingga pekerjaan inovasi juga terkait dengan masalah manajemen. Dalam kaitan ini maka sumber 
daripada inovasi adalah teknologi, sehingga dua hal ini berkaitan erat satu dengan lainnya. Walau harus dicatat bahwa teknologi bukanlah sumber satu-satunya.

Salah satu cara agar perusahaan dapat menerapkan inovasinya dengan tepat adalah dengan adanya pemimpin yag handal. Karena seperti diketahui, Seorang pemimpin dapat mendorong aktivitas usaha dan membantu para karyawan menemukan waktu untuk mengejar ide-ide produk dan proses baru atau yang ditingkatkan. Aktivitas ini biasanya hanya memerlukan sedikit investasi sumber daya dalam tahapan pengembangan. Salah satu tanggung jawab kepemimpinan yang paling penting dan paling sulit adalah memandu dan memudahkan proses pembuatan suatu perubahan besar dalam suatu organisasi. Orang cenderung untuk menolak perubahan besar karena banyak alasan, termasuk rasa tidak percaya, keraguan tentang kebutuhan akan perubahan, keraguan tentang kemungkinan perubahan, keraguan bahwa manfaatnya membenarkan harganya, ketakutan kerugian ekonomis, ketakutan kehilangan status dan kekuasaan, ketakutan akan kegagalan pribadi, persepsi bahwa perubahan tidak konsisten dengan nilai (Yukl, 2010).

Tumpuan utama perubahan dari PT Pos Indonesia adalah leadership dan entrepreneurship. Selain itu juga jaringan bisnis yang dimiliki oleh PT Pos Indonesia. Sebagai perusahaan yang bergerak dalam bidang logistik banyak hal yang harus dilakukan oelh PT Pos Indonesia. Revitalisasi yang dilakukan oleh PT Pos Indonesia diharapkan bisa menjadi tonggak awal perubahan dari PT Pos Indonesia untuk menjadi perusahaan BUMN yang bisa bersaing dengan perusahaan logistik lainnya sehingga bisa menghasilkan pemasukan keuangan bagi negara dan juga bisa memberikan layanan yang maksimal kepada konsumen yang menyebabkan penggunaan PT Pos Indonesia 
akan banyak digunakan untuk aktivitas logistik.

Berdasarkan kondisi yang telah diurakan sebelumnya, maka peneliti tertarik untuk mengkaji lebih jauh transformasi yang dilakukan oleh PT Pos Indonesia dengan tujuan khususunya sebagai berikut:

(1) Untuk mengetahui pengaruh teknologi informasi dan komunikasi terhadap kinerja PT Pos Indonesia; (2) Untuk mengetahui pengaruh kepemimpinan terhadap kinerja PT Pos Indonesia, dan (3) Untuk mengetahui pengaruh inovasi terhadap kinerja PT Pos Indonesia.

\section{KAJIAN TEORITIK}

\section{Kinerja}

Menurut Rivai (2004) kinerja merupakan hasil atau tingkatan keberhasilan seseorang secara keseluruhan selama periode tertentu dalam melaksanakan tugas dibandingkan dengan standar hasil kerja, target atau sasaran atau kriteria yang telah ditentukan terlebih dahulu dan telah disepakati bersama. Sedangkan Robbins (2008) mengatakan kinerja merupakan suatu hasil yang dicapai oleh pekerja dalam pekerjaannya menurut kriteria tertentu yang berlaku untuk suatu pekerjaan. Kinerja dipergunakan manajemen untuk melakukan penilaian secara periodik mengenai efektivitas operasional suatu organisasi (perusahaan) dan karyawan berdasarkan sasaran, standar dan kriteria yang telah ditetapkan sebelumnya. Dengan kinerja, organisasi dan manajemen dapat mengetahui sejauh mana keberhasilan dan kegagalan karyawannya dalam menjalankan amanah yang diterima.

Berdasarkan beberapa teori di atas dapat disimpulkan bahwa kinerja merupakan hasil kerja yang dapat dicapai pegawai dalam suatu organisasi, sesuai dengan wewenang dan tanggung jawab yang diberikan organisasi dalam upaya mencapai visi, misi, dan tujuan organisasi bersangkutan secara legal, tidak melanggar hukum dan sesuai dengan moral maupun etika (Thoyib, 2005). Kinerja organisasi yang baik merupakan tujuan dari setiap 
perusahaan. Pengukuran kinerja organisasi dalam penelitian ini diukur dari keempat alat ukur kinerja organisasi yang fokus pada pelanggan menurut Furtwengler (2002) dapat dijelaskan sebagai berikut; (1) Kecepatan, dalam hal ini adalah kemampuan setiap karyawan dalam memberikan pelayanan terhadap para pelanggan atau nasabah, baik pelanggan internal maupun pelanggan eksternal yang sesuai dengan Standard Operating Procedure (SOP); (2) Kualitas, adalah pelayanan yang cepat dan berkualitas yang dapat membuat para pelanggan merasa puas, menghemat waktu dan biaya; (3) Layanan, adalah layan yang diberikan oleh setiap karyawan sesuai dengan jenis pekerjannya yang diberikan pada semua pelanggan baik internal maupun ekternal akan sangat mendukung kecepatan dan kualitas pelayanan, dan (4) Nilai, adalah setiap pelanggan menginginkan nilai layanan yang cepat dan berkualitas sesuai dengan harapan pelanggan

\section{Inovasi}

Menurut Robbins dan Coulter (1999) inovasi adalah proses mengambil gagasan yang kreatif dan mengubahnya menjadi produk, jasa, atau metode operasi yang bermanfaat. Menurut Zimmerer (2002) keinovasian diartikan sebagai kemampuan untuk menerapkan kreativitas dalam rangka memecahkan persoalan dan peluang untuk mempertinggi dan meningkatkan taraf hidup. Menurut Zimmerer dan Scarborough (2008), inovasi kemampuan untuk menerapkan solusi kreatif terhadap masalah dan peluang untuk meningkatkan atau memperkaya kehidupan orang-orang.

Sehingga dapat dikatakan bahwa inovasi berangkat dari suatu yang sudah ada sebelumnya, kemudian diberi nilai tambah. Inovasi bermula dari hal yang tampak sepele dengan membuka mata dan telinga mendengarkan aspirasi atau keluhan konsumen, karyawan, lingkungan dan masyarakat. Subyek penerapan inovasi sendiri bisa individu, 
kelompok atau perusahaan. Artinya bisa terjadi dalam perusahaan ada individu atau kelompok yang sangat brilian dan inovatif. Tetapi menurut Myers dan Marquis (2003) yang ideal perusahaan menjadi tempat yang terlembagakan bagi orangorang yang terkumpul untuk mengeksploitasi ide-ide baru.

Inovasi adalah salah satu pilihan korporasi dalam menghadapi persaingan pasar dan pengelolaan yang berkelanjutan. Freeman (2004) menganggap inovasi sebagai upaya dari perusahaan melalui penggunaan teknologi dan informasi untuk mengembangkan, memproduksi dan memasarkan produk yang baru untuk industri.

Dengan kata lain inovasi adalah modifikasi atau penemuan ide untuk perbaikan secara terusmenerus serta pengembangan untuk memenuhi kebutuhan pelanggan. Ahmed dan Shepherd (2010) menyatakan inovasi perusahaan dapat menghasilkan $\mathrm{R} \& \mathrm{D}$ (Research and Development), produksi serta pendekatan pemasaran dan akhirnya mengarah kepada komersialisasi inovasi tersebut. Dengan kata lain inovasi adalah proses mewujudkan ide baru, yang berbeda dengan yang dulu, dengan cara produksi atau dengan membuatnya menjadi nyata, dimana inovasi termasuk generasi evaluasi, konsep baru dan implementasi. Di mana penggunaan metode baru dan berbeda serta teknologi untuk meningkatkan kualitas biaya atau lebih rendah, untuk memenuhi atau melampaui target perusahaan.

Ahmed dan Shepherd (2010) menyatakan inovasi tidak hanya terbatas pada benda atau barang hasil produksi, tetapi juga mencakup sikap hidup, perilaku, atau gerakangerakan menuju proses perubahan di dalam segala bentuk tata kehidupan masyarakat. Jadi, secara umum, inovasi berarti suatu ide, produk, informasi teknologi, kelembagaan, perilaku, nilai-nilai, dan praktik-praktik baru yang belum banyak diketahui, diterima, dan digunakan atau diterapkan oleh sebagian besar warga masyarakat dalam suatu lokalitas tertentu, yang 
dapat digunakan atau mendorong terjadinya perubahan-perubahan di segala aspek kehidupan masyarakat demi terwujudnya perbaikan mutu setiap individu dan seluruh warga masyarakat yang bersangkutan. Menurut Pervaiz K. Ahmed and Charles D. Shepherd, 2010, inovasi yang terjadi di dalam organisasi itu sendiri, yaitu: inovasi produk, inovasi proses dan inovasi strategi.

\section{Kepemimpinan}

Pengertian pemimpin menurut Robbins (2001) adalah "kemampuan untuk mempengaruhi suatu kelompok kearah pencapaian tujuan". Pendapat ini memandang semua anggota diberi makna sebagai kemampuan mempengaruhi semua anggota kelompok atau organisasi agar bersedia melakukan kegiatan untuk tujuan kelompok atau organisasi. Menurut Robbins (2002) dalam suatu organisasi kepemimpinan merupakan faktor yang sangat penting dalam menentukan pencapaian tujuan yang telah ditetapkan oleh organisasi. Kepemimpinan merupa- kan titik sentral dan penentu kebijakan dari kegiatan yang akan dilaksanakan dalam organisasi. Kepemimpinan adalah aktivitas untuk mempengaruhi perilaku orang lain agar supaya mereka mau diarahkan untuk mencapai tujuan tertentu.

Definisi kepemimpinan menurut Churcil dalam Nawawi (2003) adalah "Kemampuan dan keterampilan mengarahkan, merupakan faktor (aktivitas) penting dalam efektifitas pemimpin (Nevertheless, leadership abilities and skill in directing are important factors in managers effectiveness)". Yukl (2005) mengatakan kepemimpinan adalah proses mempengaruhi orang lain untuk memahami dan menyetujui apa yang perlu dilakukan dan bagaimana cara melakukan untuk memenuhi sasaran bersama. Dengan kata lain, bahwa kepemimpinan adalah cara mengartikulasikan visi, mewujudkan nilai dan menciptakan lingkungan guna mencapai sesuatu.

Kartono (2006) menjelaskan bahwa kepemimpinan merupakan 
cabang dari kelompok ilmu administrasi, khususnya ilmu administrasi negara. Dalam kepemimpinan itu terdapat hubungan antara manusia yaitu, hubungan mempengaruhi dari pemimpin dan hubungan kepatuhan-ketaatan para pengikut karena dipengaruhi oleh kewibawaan pemimpin. Para pengikut terkena pengaruh kekuatan dari pemimpinnya, dan bangkitlah secara spontan rasa ketaatan pada pemimpin.

Dari pengertian para ahli di atas dapat ditarik suatu kesimpulan, kepemimpinan adalah kemampuan mempengaruhi seseorang atau kelompok sehingga sasaran yang dicita-citakan dapat tercapai. Selain itu juga, gaya kepemimpinan sangat ditentukan dari kemampuan pemimpin dalam memimpin suatu organisasi atau perusahaan. Di mana indikator kemampuan ini dinyatakan sebagai indikator kepemimpinan menurut Yulianto (2013) terdiri dari: (1) Kemampuan memecahkan masalah (Inovativness); (2) Keberanian mengambil risiko (Risk Taking); (3) Kemampuan mempengaruhi karyawan (Proactivness); (4) Kemampuan bersaing (Competitive Agresiveness), dan (5) Kemandirian (Autonomy)

\section{Perkembangan Teknologi}

Menurut Thompson dalam Chaterine (2009) ada beberapa faktor yang merupakan kunci sukses teknologi di dalam perusahaan, antara lain: (1) Memiliki kemampuan untuk mendorong inovasi; Memiliki kemampuan teknis untuk melakukan perbaikan dalam kemampuan proses; (3) Memiliki keahlian dalam riset sains; (4) Memiliki keunggulan dalam penguasaan teknologi dibandingkan dengan pesaing

Teknologi informasi sebagai pemberdayaaan organisasi dalam merespon dan memenuhi tuntutan bisnis serta mewujudkan inovasi memerlukan pengembangan yang terencana dan terarah sesuai dengan misi organisasi. Orlikowski dan Gash dalam Atkinson (2006) memberikan definisi teknologi informasi sebagai segala bentuk sistem informasi berbasis komputer, 
yang mencakup mainframe dan aplikasi komputer. Teknologi informasi adalah sesuatu yang digunakan untuk menciptakan sistem informasi, yang semuanya merupakan perangkat keras serta perangkat lunak yang digunakan untuk mengimplementasikan sistem yang berbasis komputer (Callon, dalam Basu, 1998). Sarosa dan Zowghi (2003) menyimpulkan istilah teknologi informasi adalah semua teknologi yang digunakan untuk mengumpulkan, memproses dan menyebarkan informasi.

Venkatraman dan Zaher dalam Atkinson (2006) mengatakan, globalisasi dan meningkatnya persaingan internasional mempercepat gerakan ke arah pemanfaatan TI yang semakin meningkat oleh organisasi-organisasi. Meningkatnya kepentingan koordinasi operasi tingkat dunia dan perlunya reaksi yang cepat terhadap ancaman persaingan dunia menegaskan akan pentingnya $\mathrm{TI}$ dalam konteks bisnis saat ini. Ketersedianya teknologi dalam suatu organisasi tentunya akan meningkatkan pelayanan (lacovou et al., dalam Croteau dan $\mathrm{Li}, 2003)$.

Pendapat serupa juga dikemukan oleh Porter dan Miller dalam Atkinson (2006) bahwa tujuan utama aplikasi teknologi informasi pada organisasi adalah untuk mengkoordiasi aktivitas organisasi. Sementara itu, Reckoff et al. dalam Atkinson (2006) mengatakan bahwa teknologi informasi yang ada di organisasi harus mampu mendukung langkah kompetitif, seperti kepemimpinan, diferensiasi, inovasi, pertumbuhan serta mampu memecahkan masalah koordinasi di antara departemen.

Variabel teknologi informasi dibentuk oleh lima indikator yaitu intensitas teknologi informasi, ketersediaan tenaga ahli, investasi pada teknologi, kemudahan bertukar informasi, dan kemudahan akses bekerjasama

\section{METODE PENELITIAN}

Metode penelitian ini adalah explanatory survey, sebagai upaya mengumpulkan informasi dari responden dengan menggunakan 
angket. Penelitian ini dimaksudkan untuk "menguji jawaban rasional sehingga dapat menjelaskan fenomena yang menjadi masalah". Selain itu, metode survey digunakan meluas dan mendalam terhadap obyek yang diteliti, setidaknya secara parsial, yakni pendekatan menyeluruh yang didasarkan pada sistemnya. Populasi dalam penelitian ini adalah seluruh karyawan PT. Pos Indonesia. Mengingat jumlah populasinya tidak terbatas, maka penelitian akan dilakukan dengan menggunakan sampel acak dalam jumlah tertentu.

\section{HASIL DAN PEMBAHASAN}

\section{Hasil Penelitian}

Sebelum melakukan pengujian hipotesis penelitian terlebih dahulu dilakukan analisis regresi linear berganda. Adapun ringkasan analisis regresi linear berganda yang dilakukan dengan alat bantu program SPSS 17.0 adalah:

Coefficients $^{\mathrm{a}}$

Tabel 1. Rangkuman Hasil Uji Regresi Linear Berganda

\begin{tabular}{|ll|l|l|l|l|l|}
\hline \multirow{2}{*}{ Model } & \multicolumn{3}{|l|}{ Unstandardized Coefficients } & \multicolumn{2}{l|}{$\begin{array}{l}\text { Standardized } \\
\text { Coefficients }\end{array}$} & \multirow{2}{*}{} \\
\cline { 2 - 5 } & & $\mathrm{B}$ & Std. Error & Beta & Sig. \\
\hline 1 & (Constant) & 4.154 & .348 & & 11.953 & .000 \\
& Teknologi & .134 & .031 & .169 & 4.311 & .000 \\
& Inovasi & .320 & .065 & .204 & 4.933 & .000 \\
& Kepemimpinan & .472 & .031 & .659 & 15.028 & .000 \\
\hline
\end{tabular}

a. Dependent Variable: Kinerja

Berdasarkan Tabel 4.4. bebasnya atau Perkembangan diperoleh persamaan regresi linear berganda sebagai berikut: $Y=4,154$ teknologi (X1), Inovasi (X2) dan $+0,134 X 1+0,320 X 2+0,472 X 3$. Kepemimpinan (X3) bernilai nol, Dari persamaan regresi linier berganda diatas diperoleh nilai konstanta sebesar 4,154 Artinya, jika variabel Kinerja (Y) tidak dipengaruhi oleh ketiga variabel maka besarnya rata-rata Kinerja akan bernilai $(4,154)$.

Nilai koefisien regresi pada variabel-variabel bebasnya menggambarkan apabila diperkirakan variabel bebasnya naik sebesar satu 
unit dan nilai variabel bebas lainnya diperkirakan konstan atau sama dengan nol, maka nilai variabel terikat diperkirakan bisa naik atau bisa turun sesuai dengan tanda koefisien regresi variabel bebasnya.

Koefisien regresi untuk variabel bebas $\mathrm{X} 1$ (Perkembangan teknologi) bernilai positif, menunjukkan adanya hubungan yang searah antara Perkembangan teknologi (X1) dengan Kinerja (Y). Koefisien regresi variabel $\mathrm{X} 1$ sebesar 0.134 mengandung arti untuk setiap pertambahan Perkembangan teknologi (X1) sebesar satu satuan akan menyebabkan kenaikan kinerja $(\mathrm{Y})$ sebesar 0.134 . Koefisien regresi untuk variabel bebas X2 ( inovasi) bernilai positif, menunjukkan adanya hubungan yang searah antara inovasi (X2) dengan kinerja (Y). Koefisien regresi variabel $\mathrm{X} 2$ sebesar 0,320 mengandung arti untuk setiap inovasi (X2) sebesar satu satuan akan menyebabkan meningkatnya kinerja ( $\mathrm{Y}$ ) sebesar 0,320 . Koefisien regresi untuk variabel bebas X3 (Kepemimpinan) bernilai positif, menunjukkan adanya hubungan yang searah antara kepemimpinan (X3) dengan Kinerja $(Y)$. Koefisien regresi variabel $X 3$ sebesar 0.472 mengandung arti untuk setiap pertambahan kepemimpinan (X3) sebesar satu satuan akan menyebabkan peningkatan kinerja $(Y)$ sebesar 0.472 .

Selanjutnya untuk menguji apakah pengaruh perkembangan teknologi, inovasi dan kepemimpinan terhadap kinerja signifikan secara parsial (individual), dilakukan uji signifikansi. Untuk mengetahui variabel yang berpengaruh signifikan secara parsial dilakukan pengujian koefisien regresi dengan menggunakan statistik Uji t. Penentuan hasil pengujian (penerimaan/penolakan H0) dapat dilakukan dengan membandingkan t-hitung dengan $\mathrm{t}$ tabel atau juga dapat dilihat dari nilai signifikansinya. Hasil pengujian hipotesis secara parsial dengan menggunakan spss adalah sebagai berikut: 
Coefficients $^{\mathrm{a}}$

Tabel 2 Uji Hipotesis Parsial

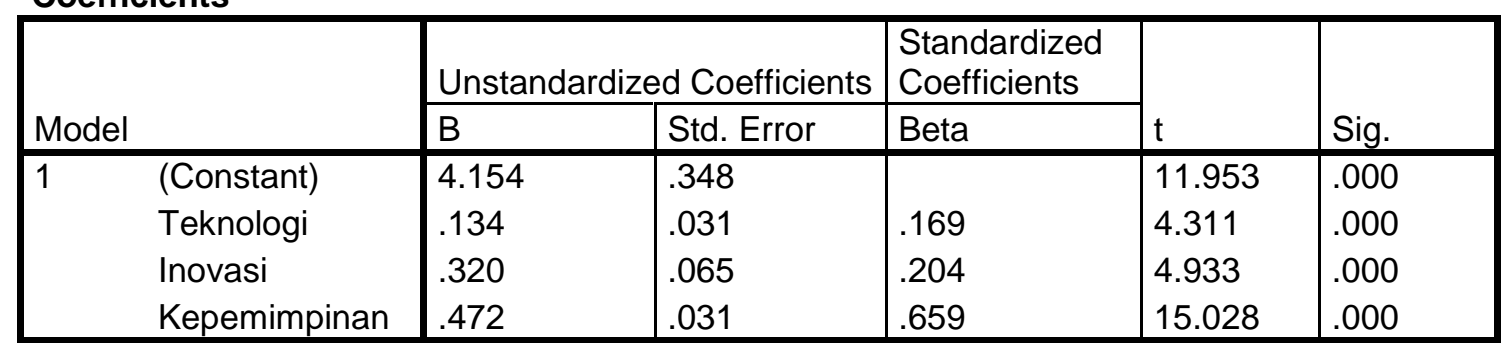

a. Dependent Variable: Kinerja

Hasil pengujian pengaruh setiap variabel independent (perkembangan teknologi, inovasi dan kepemimpinan ) terhadap variabel dependent (kinerja) di lingkungan PT POS Indonesia adalah sebagai berikut: Nilai prob. $t$ hitung dari variabel bebas Perkembangan Teknologi sebesar 0,000 yang lebih kecil dari 0,05 sehingga variabel bebas Perkembangan Teknologi berpengaruh signifikan terhadap variabel terikat Kinerja pada alpha 5\% atau dengan kata lain, Perkembangan Teknologi berpengaruh signifikan terhadap Kinerja. Nilai prob. t hitung dari variabel bebas Inovasi sebesar 0,000 yang lebih kecil dari 0,05 sehingga variabel bebas Inovasi berpengaruh signifikan terhadap variabel terikat Kinerja pada alpha $5 \%$ atau dengan kata lain, Inovasi berpengaruh signifikan terhadap Kinerja. Nilai prob. $t$ hitung dari variabel bebas Inovasi sebesar 0,000 yang lebih kecil dari 0,05 sehingga variabel bebas Kepemimpinan berpengaruh signifikan terhadap variabel terikat Kinerja pada alpha 5\% atau dengan kata lain, Kepemimpinan berpengaruh signifikan terhadap Kinerja.

Selanjutnya ditentukan Koefisien determinasi yang pada intinya mengukur seberapa jauh kemampuan model dalam menerangkan variasi variabel. Koefisien determinasi ini digunkan karena dapat menjelaskan kebaikan dari model regresi dalam variabel dependen. Semakin tinggi nilai koefisien determinasi maka akan semakin baik pula kemampuan variabel independen dalam menjelaskan variabel dependen. Nilai koefisien 
determinasi adalah antara nol dan satu. Nilai R2 yang kecil berarti kemampuan variabel-variabel independen dalam menjelaskan variasi variabel dependen amat terbatas. Nilai yang mendekati satu berarti variabel-variabel independen memberikan hampir semua informasi yang dibutuhkan untuk memprediksikan variasi variabel dependen.

Dengan menggunakan spss 17.0 diperoleh koefisien determinasi sebagai berikut :

Tabel 3 Koefisien Determinasi
\begin{tabular}{|l|l|l|l|l|}
\hline Model Summary \\
\hline Model & $\mathrm{R}$ & $\mathrm{R}$ Square & $\begin{array}{l}\text { Adjusted } \\
\text { Square }\end{array}$ & $\mathrm{R}$ \\
\hline 1 & $\begin{array}{l}\text { Std. Error of } \\
\text { the Estimate }\end{array}$ \\
\hline
\end{tabular}

a. Predictors: (Constant), Kepemimpinan, Teknologi, Inovasi

Dari hasil output SPSS tersebut dapat dilihat bahwa nilai koefisien determinasi atau $\mathrm{R}$ Square sebesar 0,095 atau 95\%. Hal ini menunjukan bahwa variabel yang diteliti (inovasi) memberikan pengaruh terhadap Kinerja sebesar $95 \%$, sedangkan sisanya dipengaruhi variabel yang tidak diteliti (variabel pengganggu).

\section{Pembahasan}

Pada analisis model pengukuran dalam penelitian ini menunjukan bahwa seluruh variabel telah memenuhi kriteria validitas dan reliabilitas, sedangkan pada analisis model struktural diperoleh bahwa hipotesis pertama, kedua dan ketiga $(\mathrm{H} 1, \mathrm{H} 2$ dan $\mathrm{H} 3)$ seluruhnya mendukung hipotesis yang diajukan. Hasil pengujian dari model struktural untuk tiap-tiap hipotesis sebagai berikut:

Hasil uji pengaruh perkembangan teknologi terhadap kinerja. Perkembangan Teknologi merupakan rangkaian proses, peralatan, metode, prosedur, dan piranti yang digunakan untuk memproduksi barang atau jasa. Variabel teknologi informasi dibentuk oleh lima indikator yaitu intensitas teknologi informasi, ketersediaan tenaga ahli, investasi pada teknologi, kemudahan bertukar informasi, dan 
kemudahan akses bekerjasama. Hasil analisis menunjukan bahwa perkembangan teknologi memberikan pengaruh yang signifikan terhadap peningkatan kinerja di lingkungan PT POS Indonesia. Hasil ini sejalan dengan penelitian sebelumnya yang dilakukan oleh Benhur Tomi Mano, Armanu Thoyib, Ghozali Maskie dan Djumahir, (2014) yang menyimpulkan bahwa teknologi berpengaruh secara signifikan terhadap kinerja.

Pengaruh inovasi terhadap kinerja. Inovasi merupakan Kemampuan untuk mengembangkan kreativitas dalam rangka memecahkan berbagai permasalahan yang terjadi. Variabel inovasi dibentuk oleh beberapa indikator yaitu inovasi proses, inovasi produk dan inovasi strategi. Berdasarkan analisis yang dilakukan inovasi merupakan salah satu faktor yang mempengaruhi kinerja. Peningkatan inovasi akan diikuti dengan peningkatan kinerja. Bahkan berdasarkan analisis tersebut pengaruh inovasi terhadap kinerja cukup signifikan. Hal ini sejalan dengan penelitian Hartini (2012) dan Benhur Tomi Mano, Armanu Thoyib, Ghozali Maskie dan Djumahir, (2014) yang menyimpulkan bahwa inovasi mempengaruhi kinerja secara nyata

Hasil Uji Pengaruh kepemimpinan terhadap kinerja. Kepemimpinan adalah suatu proses yang dilakukan manajer perusahaan untuk mengarahkan (directing) dan mempengaruhi (influencing) para bawahannya dalam kegiatan yang berhubungan dengan tugas (Solihin) serta proses memotivasi pihak lain untuk bekerja sesuai tujuan tertentu (Widiyono dan Pakkanna). Variabel kepemimpinan dibentuk oleh lima indikator yaitu Kemampuan memecahkan masalah (Inovativness), Keberanian mengambil risiko (Risk Taking), Kemampuan mempengaruhi karyawan (Proactivness), Kemampuan bersaing. Hasil analisis menunjukan bahwa kepemimpinan berpengaruh signifikan terhadap peningkatan kinerja di lingkungan PT POS Indonesia. Hasil ini sejalan dengan penelitian sebelumnya yang dilakukan oleh Benhur Tomi Mano, 
Armanu Thoyib, Ghozali Maskie dan Djumahir, (2014) yang menyimpulkan bahwa kepemimpinan berpengaruh secara signifikan terhadap kinerja. Berdasarkan data yang dijadikan dasar penelitian ini dapat dilihat bahwa hubungan antara kepemimpinan dengan kinerja bersifat fluktuatif. Artinya ada saat dimana kepemimpinan naik namun kinerja turun. Sehingga dapat disimpulkan bahwa kepemimpinan tidak berpengaruh secara segnifikan terhadap kinerja.

Nilai R-Square (0.950), menunjukkan bahwa ketiga variabel independent/bebas yang terdiri dari perkembangan teknologi, inovasi dan kepemimpinan memberikan kontribusi/pengaruh sebesar 95\% terhadap peningkatan dan penurunan kinerja di PT. POS Indonesia. Sisanya merupakan pengaruh faktor lain diluar ketiga variabel bebas yang diteliti. Seperti halnya penelitian Prastyo (2011) Benhur Tomi Mano, Armanu Thoyib, Ghozali Maskie dan Djumahir, (2014) yang tidak hanya meneliti perkembangan teknologi, inovasi dan kepemimpinan, namun juga meneliti variabel lain seperti budaya.

\section{KESIMPULAN DAN SARAN}

Penelitian ini bertujuan untuk mengetahui Pengaruh Perkembangan Teknologi Informasi dan Komunikasi, Kepemimpinan dan Inovasi Terhadap Kinerja Perusahaan (Studi Transformasi PT. Pos Indonesia). Kesimpulan dalam penelitian ini: (1) Terdapat pengaruh Perkembangan teknologi terhadap Kinerja. Berdasarkan output diketahui nilai t-hitung sebesar 0,000 lebih kecil dari 0,05. Jika dibandingkan dengan nilai t-tabel sebesar 0,5 maka t-hitung yang diperoleh jauh lebih kecil dari nilai ttabel. Sehingga dapat disimpulkan bahwa variabel perkembangan teknologi berpengaruh secara signifikan terhadap kinerja; Terdapat pengaruh inovasi terhadap kinerja. Berdasarkan output diketahui nilai t-hitung sebesar 0,000 . Jika dibandingkan dengan nilai t-tabel sebesar 0,005 maka thitung yang diperoleh lebih kecil dari nilai t-tabel. Sehingga dapat 
disimpulkan bahwa variabel inovasi berpengaruh secara signifikan terhadap kinerja, dan (3) Tidak terdapat pengaruh Kepemimpinan terhadap Kinerja. Berdasarkan output diketahui nilai t-hitung sebesar 0,000. Jika dibandingkan dengan nilai t-tabel sebesar 0,005 maka t-hitung yang diperoleh lebih kecil dari nilai t-tabel. Sehingga dapat disimpulkan bahwa variabel kepemimpinan berpengaruh secara signifikan terhadap kinerja.

Penelitian ini memberikan beberapa implikasi mengenai Pengaruh Perkembangan Teknologi Informasi, Kepemimpinan dan Inovasi Terhadap Kinerja Perusahaan (Studi Transformasi PT. Pos Indonesia). Penelitian ini dapat dijadikan sebagai perbandingan untuk kepentingan praktisi dalam mengukur tingkat Pengaruh Perkembangan Teknologi Informasi, Kepemimpinan dan Inovasi Terhadap Kinerja Perusahaan.

\section{DAFTAR PUSTAKA}

Amabile et all (1996), Assesing The Work Environment for creativity". Academy of Management Journal, Vol. 39, No.5, p.1154-1184.

Anderson and Anderson. (2001). Beyond Change Management: Advanced Strategies For Today's Transformational Leaders. San Francisco, CA Anggoro. (2000). Teori dan Profesi Kehumasan Serta Aplikasinya di Indonesia. Jakarta : PT Bumi Aksara.

Ariesto Hadi Sutopo. (2012). Teknologi Informasi dan Komunikasi dalam Pendidikan, Edisi Pertama. Yogyakarta: Graha IImu.

Ashar Sunyoto Munandar. (2001). Psikologi industri dan organisasi. UI -Press, Jakarta.

Atkinson. 2006. Strategy Implementation: A Role for The Balanced Scorecard?. Management Decision

Avanti Fontana. (2009). Innovate We Can !, How to Create Value through Innovation in Your Organization and Scociety. Jakarta: Grasindo

Basu Swastha Dharmmesta. (1998). Teknologi Informasi dalam Pemasaran : Implikasi dalam Pendidikan Pemasaran. Jurnal Ekonomi dan Bisnis Indonesia, Vol. 13, No. 3, pp. $116-125$.

Benhur Tomi Mano, Armanu Thoyib, Ghozali Maskie dan Djumahir,. (2014). Effect of Transformational Leadership Style, Information Technology, Organization Culture and Leader Innovation on Leader Performance (Study in Jayapura City Government), 
International Journal of Business and Management Invention ISSN (Online): 2319 - 8028, ISSN (Print): 2319 $801 X$

Benjamin. (2006). Leadership Style and Regulatory Mode: Value from Fit? Organizational Behavior and Human Decision Processes. pp. 216230

Brahmasari. (2008). Pengaruh Motivasi Kerja, Kepemimpinan dan Budaya Organisasi Terhadap Kepuasan Kerja Karyawan serta Dampaknya pada Kinerja Perusahaan (Studi kasus pada PT. Pei Hai International Wiratama Indonesia). Jurnal Manajemen dan Kewirausahaan, 10(2), 124-135

Buchari Alma. (2009). Pengantar Bisnis. Bandung: Alfabeta

De Jong \& Den Hartog. (2003). Leadership as a determinant of innovative behaviour. A Conceptual framework. http://www.eim.net/pdf-ez/ H200303.pdf

De Wit, B. and Meyer, R. (2004). Strategy Process, Content, and Context International Perspective, (3rd ed.), Thomson Learning

Departemen Komunikasi dan Informatika. (2005). Buku Putih TIK. Jakarta: Depkominfo.

Everett M. Rogers. (2003). Diffusion of Innovation. Canada: The Free Press of Macmillan Publishing Co

Ferdinand. (2006). Structural Equation Modelling Dalam Penelitian Manajemen. Semarang:
Badan Penerbit Universitas Diponegoro.

Freeman. (2004). The Economics of Industrial Innovation (3rd Ed). London: Taylor and Franch Group.

Furtwengler. (2002). Penilaian Kinerja, Menguasai Keahlian yang anda Perlukan dalam 10 menit. Yogyakarta: Andi Offset.

Gary Yukl. (2010). Kepemimpinan dalam Organisasi, Edisi Kelima. Jakarta: PT. Indeks.

Hadari Nawawi. (2003). Kepemimpinan yang efektif. Yogyakarta: Gajah Mada University Press.

Hadari. (2002). Manajemen Sumber Daya Manusia Untuk Bisnis Yang Kompetitif. Yogyakarta: Gajah Mada University Press.

Handoko. (2001). Manajemen Personalia Dan Sumber Daya Manusia. Yogyakarta : BPFE.

Heidjrachman dan Husnan. (2008). Manajemen Personalia. Yogyakarta : BPFE.

Hussey. (2003). The Innovation Challenge. New York: John Wiley \& Sons. . (2000). How to Manage Organizational Change. London: Kogan Page Limited. Hyland \&Beckett. (2004). Innovation and enhancement of enterprise capabilities. International Journal of Technology Management and Sustainable 3 (1) $35-46$.

Kaiser, U. (2004), Strategic Complementarities Between Different Types of ICTexpenditures. Discussion Paper No. 03-46. 
Kartini Kartono, 2006, Pengantar Metode Penelitian. Jakarta: UI Press.

Kasali, 2005, Change. Jakarta: Gramedia Pustaka Utama

Kementerian Negara Riset dan Teknologi, 2006, Buku Putih. Penelitian Pengembangan dan Penerapan IPTEK Bidang Teknologi Informasi dan Komunikasi Tahun 20052025. Jakarta: Kementerian Negara Riset dan Teknologi.

Kreitner dan Kinicki. (2001). Organizational Behavior. Homewood, Illionis: Richard D. Irwin, Inc.

Limsurapong et al. (2010). Organizational Innovation Strategy and Firm Performance : an empirical study of computer spare parts business in Thailand. IJSM. Volume 10, Number 2.

Mangkuprawira. (2004). Manajemen Sumber Daya Manusia. Strategik. Jakarta : Ghalia Indonesia

Miftah Thoha. (2010). Perilaku Organisasi Konsep Dasar dan Aplikasinya. Jakarta : Raja Grafindo Persada.

Muhamad Amin \& Richard Kumaradjaja. (2009). Strategi Change Management Untuk Mempercepat Implementasi Penggunaan Aplikasi Perangkat Lunak Berbasis Open Source: Studi Kasus Kementerian Negara Riset Dan Teknologi. Journal of Business Strategy and Execution Vol. 1 No.2 Juni.

Murat Atalay, Nilgun Afarta dan Fulya Sarvan. (2013). The relationship between innovation and firm performance: An empirical evidence from Turkish automotive supplier industry, 2nd International Conference on Leadership, Technology and Innovation Management, Procedia Social and Behavioral Sciences 75 ( 2013 ) 226 235.

Rahardja dan Manurung. (2008). Teori Ekonomi Makro: Suatu. Pengantar. Jakarta: Lembaga Penerbit FE UI.

Robbins \& Coulter. (1999). Management. Prentice-Hall, Englewood Cliffs, NJ

Robbins. (2008). Perilaku Organisasi Jilid Pertama. Edisi Sepuluh. Jakarta: Pearson Education Asia Pte. Pt Prehallindo.

Sampurno. (2010). Manajemen Stratejik:Menciptakan

Keunggulan Bersaing Yang Berkelanjutan. Yogyakarta: Gadjah Mada University Press.

Soekarso ,et al. (2010). Teori Kepemimpinan. Jakarta: Mitra Wacana Media.

Soerjono Soekanto. (2001). Sosiologi. Jakarta: PT Rajagrafindo Persada.

Sri Hartini. (2012). Peran inovasi: pengembangan kualitas produk dan kinerja bisnis. Jurnal manajemen dan kewirausahaan, vol.14, no. 1, maret 2012:63-90.

Stephen P. (2002). Prinsip-prinsip Perilaku Organisasi. Edisi kelima. Jakarta: Penerbit Erlangga. 
Sudarwan Danim. (2004). Motivasi Kepemimpinan dan Efektivitas Kelompok. Jakarta: PT Rineka Cipta.

Sutojo. (2004). Membangun Citra Perusahaan. Jakarta: Damar Mulia Pustaka

Syafrin Azuari. (2010). Dampak Pengeluaran Teknologi Informasi Dan Komunikasi Terhadap Perekonomian Indonesia : Analisis Sistem Neraca Sosial Ekonomi. Jakarta: Fakultas Ekonomi Program Magister Perencanaan Dan Kebijakan Publik.

Thomas W. Zimmerer dan Norman M. Scarborough. (2008). Essential of Entrepreneurship and Small Business Management. New Jersey: Prentice-Hall Inc.

Tjiptono. (2006). Manajemen Jasa. Edisi Kedua. Yogyakarta: Andi. Offset

Todaro. (2006). Pembangunan Ekonomi. Jilid I Edisi
Kesembilan. Jakarta: Erlangga.

Tucker dan Lewis. (2004). The Influence of the Transformasional Leader. Journal of Leadership and Organizational Studies, 10 (4).

Veithzal Rivai. (2004). Manajemen Sumber Daya Manusia Untuk Perusahaan : Dari Teori Ke Praktik. Jakarta: PT. Raja Grafindo Persada.

Wahyudi. (2009). Manajemen Sumber Daya Manusia. Bandung: PT. Remaja Rosda Karya.

Wibowo. (2011). Manajemen Perubahan. PT. Rajagrafindo Persada, Jakarta

Winardi. (2008). Manajemen Perilaku Organisasi. Jakarta: Prenada Media.

Yukl. (2005). Kepemimpinan Dalam Organisasi. Edisi Kelima. Jakarta: PT Indeks.

Zimmerer. (2002). Pengantar Kewirausahaan Dan Manajemen Bisnis Kecil. Jakarta. Jakarta : PT. Rineka Cipta 